\title{
Correlation among agronomic, physiological and phytochemical traits in Artemisia annua L. varieties
}

\author{
BOLINA, C.O. ${ }^{1}$; MARCHESE J.A. ${ }^{1 *}$; CAPELIN D. ${ }^{1}$; BERTONCELLI D.J. ${ }^{1}$; PINNOW C. ${ }^{1}$; BENIN G. ${ }^{1}$; FOGLIO, \\ M.A. ${ }^{2}$ \\ ${ }^{1}$ Universidade Tecnológica Federal do Paraná, Campus Pato Branco, Via do Conhecimento, Km 01, CEP $85503-$ \\ 390, Pato Branco- PR, Brasil *abramo@pq.cnpq.br ${ }^{2}$ Centro Pluridisciplinar de Pesquisas Químicas, Biológicas \\ e Agronômicas, Universidade Estadual de Campinas, Caixa Postal 6171, 13081-970, Paulínia, SP, Brasil.
}

\begin{abstract}
RESUMO: Correlação entre caracteres agronômicos, fisiológicos e fitoquímicos em variedades de Artemisia annua L. O objetivo deste trabalho foi estimar as correlações existentes entre caracteres agronômicos, fisiológicos e fitoquímicos em duas variedades de Artemisia annua e identificar correlações que possam ser utilizadas em processos de seleção e melhoramento da espécie. O delineamento foi inteiramente casualizado e os tratamentos foram às variedades $2 / 39 \times 5 \times 3 \mathrm{M} \mathrm{e} 2 / 39 \times 1 \mathrm{~V}$ de Artemisia annua, submetidas a avaliações agronômicas, fisiológicas e fitoquímicas. A relação existente entre os caracteres estudados foi estimada através do coeficiente de correlação de Pearson e o nível de significância das correlações pelo teste t, realizadas no programa Genes. Encontrou-se correlação positiva e significativa entre os caracteres volume de dossel e rendimento de óleo essencial na variedade $2 / 39 \times 5 \times 3 \mathrm{M}$, evidenciando que a seleção de plantas com maior volume de dossel possibilitaria a seleção indireta para o cárater rendimento de óleo essencial. Esta correlação não foi encontrada na variedade $2 / 39 \times 1 \mathrm{~V}$. Em ambas as variedades, observou-se correlação negativa e significativa entre volume de dossel e teor de artemisinina indicando que deve-se evitar a seleção de plantas com grande volume de dossel e número de ramificações, se o interesse do melhoramento for maior teor de artemisinina.
\end{abstract}

Palavras-chave: Artemisia, artemisinina, óleo essencial, correlação, seleção de genitores.

ABSTRACT: The aim of this study was to estimate the correlations among agronomic, physiological and phytochemical traits of two varieties of Artemisia annua and to identify correlations that can be used in selection and breeding processes for this species. The design was completely randomized and the treatments were for Artemisia annua varieties $2 / 39 \times 5 \times 3 \mathrm{M}$ and $2 / 39 \times 1 \mathrm{~V}$, which were subjected to agronomic, physiological and phytochemical evaluations. The relationship among the studied traits was estimated with Pearson's correlation coefficient, and the significance level of correlations was established by the t-test using Genes software. A significant positive correlation was found between the traits canopy volume and essential oil yield for $2 / 39 \times 5 \times 3 \mathrm{M}$ variety, showing that the selection of plants with a larger canopy volume would facilitate indirect selection of the trait essential oil yield. This correlation was not found for the $2 / 39 \times 1 \mathrm{~V}$ variety. In both varieties, there was a significant negative correlation between canopy volume and artemisinin content, which suggested that the selection of plants with a large canopy volume and a large number of branches should be avoided if the goal is to increase artemisinin content.

Key words: Wormwood, artemisinin, essential oil, correlation, parent selection.

\section{INTRODUCTION}

Artemisia annua L. (Asteraceae) is an aromatic annual herb native to China and acclimatized in Brazil (Marchese \& Rehder, 2001; Marchese et al., 2005). The herb's leaves are a source of artemisinin, a sesquiterpene lactone effective against resistant strains of Plasmodium falciparum that cause cerebral malaria (Ferreira \& Janick, 1996) and are selectively cytotoxic to cancer cells (Ferreira, 2004; Efferth, 2007). Additionally, this species is a source of essential oil, which is commercially used in the perfume and cosmetic industries (Jain et al., 1996; Magalhães et al., 2004).

Recebido para publicação em 01/06/2011

Aceito para publicação em 19/10/2012

Rev. Bras. Pl. Med., Botucatu, v.15, n.1, p.135-141, 2013. 
The herb's low yields of artemisinin have been the limiting factor for artemisinin's large-scale isolation (Charles \& Simon, 1990). Thus, breeding programs for $A$. annua seek to select late-flowering genotypes with high artemisinin contents and high leaf biomass production, which facilitates an increase in the production of artemisinin from $5 \mathrm{~kg}$ ha-1 $^{-1}$ to $25 \mathrm{~kg} \mathrm{ha}^{-1}$ (Magalhães et al., 1997, 1999). Studies conducted by Magalhães et al. (1999) found an artemisinin yield of $21.38 \mathrm{~kg} \mathrm{ha}^{-1}$ and a phytomass production of $2,056.05 \mathrm{~kg} \mathrm{ha}^{-1}$. Marchese (2006) found an artemisinin yield of $30.38 \mathrm{~kg} \mathrm{ha}^{-1}$ and a phytomass production of $3,045.10 \mathrm{~kg} \mathrm{ha}^{-1}$. The higher phytomass production described by Marchese (2006) resulted in a larger artemisinin yield per area planted with $A$. annua and, according to Kumar et al. (2004), increasing production by increasing the planted area is one method to improve the yield of this compound.

With the increasing worldwide demand for artemisinin and artemisinin analogs, the limitation on artemisinin production on an industrial scale because of low yield and the high cost of the molecule's extraction and purification make it important to identify the traits correlated to larger biomass and artemisinin yields. The correlated traits can assist in the selection process and decrease costs because of the straightforwardness of selecting traits that enable more practical measurements, which can result in greater genetic progress. A positive correlation between the biomass production and the artemisinin yield was found by Magalhães (1996) and Marchese (2006); moreover, the artemisinin content exhibited a direct correlation with plant height and branching intensity (Liao et al., 2009, Paul et al., 2010) and a high correlation (0.987) with trichome density (Zhang et al. 2006). Regarding the essential oil yield, Marchese and Figueira (2005) reported that this trait can be correlated with photosynthesis because increased oil production is typically associated with higher radiation and a higher photosynthetic rate in plants.

Thus, knowledge of the association between traits is important to the improvement of a species, particularly when the selection of one of the traits poses difficulties because of low heritability or problems related to measurement and identification (Cruz \& Regazzi, 2001). Less complex characters with high heritability and high correlations favor selection efficiency and assist the improvement of the species (Nunes et al., 2008; Almeida et al., 2010). The present study aimed to estimate the correlations between agronomic, physiological and phytochemicals traits in two $A$. annua varieties and to identify correlations that can be used in the selection and breeding of this species.

\section{MATERIALS AND METHODS}

The study was conducted at the experimental area of the Department of Agronomy of the Federal Technological University of Paraná [Universidade Tecnológica Federal do Paraná - UTFPR], located in Pato Branco, Paraná State (PR), Brazil, at latitude $26^{\circ} 11^{\prime} \mathrm{S}$, longitude $52^{\circ} 36^{\prime} \mathrm{W}$ and $760 \mathrm{~m}$ altitude. The climate at the experimental area is subtropical (Cfa) according to Köppen's classification. Seeds of $A$. annua varieties $2 / 39 \times 5 \times 3 \mathrm{M}$ and $2 / 39 \times 1 \mathrm{~V}$ were sown in planting grids of 96 cells that contained 130 $\mathrm{g}$ of sterile Tecnomax ${ }^{\circledR}$ organic substrate. A total of 192 cells were used per variety, and the cells were maintained in plastic incubators during a photoperiod of 15 hours to prevent the plants from flowering. In October 2009, on reaching a height of $20 \mathrm{~cm}$, the plants were transplanted to the field. The experiment followed a completely randomized design, and the treatments were performed for the two varieties, which were represented by 15 plants/individuals each. The spacing was $1 \times 1 \mathrm{~m}$ between plants and $3 \mathrm{~m}$ between varieties.

Acidity correction and fertilization were performed based on soil chemical analysis following the recommendations of the Chemistry and Soil Fertility Commission for the states of Rio Grande do Sul and Santa Catarina (CQFS-RS/SC) [Comissão de Química e Fertilidade do Solo - RS/SC] in the formulations with urea, single superphosphate and potassium chloride ( $\mathrm{N}: 160 \mathrm{~kg} \mathrm{ha}^{-1}, \mathrm{P}: 175 \mathrm{~kg} \mathrm{ha}^{-1}$, $\left.\mathrm{K}: 90 \mathrm{~kg} \mathrm{ha}^{-1}\right)$. A topdress nitrogen ( $\left.\mathrm{N}\right)$ application was divided into two applications of $28 \mathrm{~kg} \mathrm{ha}^{-1}$ during the crop cycle (11/16/2009 and 12/16/2009), and the entire experimental area was fertilized.

\section{Agronomic assessments}

In January 2010, the first plant selection was made, and the plants that were larger and had a larger number of leaves were chosen. At this stage, 50 plants of each variety were selected and identified with acrylic tags tied to the plants' apex. The tags numbered from B1 to B50 identified the population that originated from $2 / 39 \times 5 \times 3 \mathrm{M}$ variety, whereas the tags numbered from $\mathrm{C} 1$ to $\mathrm{C} 50$ identified the population that originated from $2 / 39 \times 1 \mathrm{~V}$ variety. When $50 \%$ of the selected plants began producing flower buds, a second visual selection was performed on the 50 initially selected plants. In each population, 8 plants that were taller and had greater leaf biomass were separated for the evaluation of their agronomic, physiological and phytochemical traits. A sample of eight plants was used because of the difficulties in performing physiological evaluations of a large number of plants. This approach was influenced by the fragility of $A$. annua leaves that, when coupled to the infrared gas analyzer (IRGA), detach easily from the branches and interrupt the gas exchange measurement.

Rev. Bras. PI. Med., Botucatu, v.15, n.1, p.135-141, 2013. 
The measured agronomic traits were: the plant height $(\mathrm{Ht}, \mathrm{m})$, the insertion height of the first pair of plagiotropic branches $(\mathrm{Hi}, \mathrm{m})$, the canopy height $(\mathrm{Hc}, \mathrm{m})$, the diameter of the canopy's lower section (DI, $\mathrm{m}$ ), the diameter of the canopy's middle section $(\mathrm{Dm}, \mathrm{m})$, the diameter of the canopy's upper section (Du, m), the stem diameter (Ds, cm), the number of branches (NB) and the canopy volume $\left(\mathrm{Vc}, \mathrm{m}^{3}\right)$. The canopy volume was estimated by the equation $\mathrm{Vc}_{\mathrm{c}}=\partial \mathrm{Di}^{2} \mathrm{Hd} / 12$ according to the method of Favarin et al. (2002).

\section{Physiological evaluation}

The determined physiological variables included the following: the leaf area (LA, $\mathrm{cm}^{2}$ ); the rate of $\mathrm{CO}_{2}$ assimilation $\left(P_{\mathrm{N}}\right.$ ìmol $\left.\mathrm{CO}_{2} \mathrm{~m}^{-2} \mathrm{~s}^{-1}\right)$; the stomatal conductance $\left(g_{\mathrm{s}}, \mathrm{mol} \mathrm{H}_{2} \mathrm{O} \mathrm{m}^{-2} \mathrm{~s}^{-1}\right)$; the intracellular concentration of $\mathrm{CO}_{2}\left(\mathrm{C}_{\mathrm{i}}\right.$, imol $\mathrm{CO}_{2} \mathrm{~mol}^{-}$ $1)$; the transpiration rate $\left(E, \mathrm{mmol} \mathrm{H}_{2} \mathrm{O} \mathrm{m}^{-2} \mathrm{~s}^{-1}\right)$ and the water use efficiency (WUE, \%).

Physiological measurements were performed by using an open gas-exchange measuring system equipped with an IRGA model LI-6400XT (LI-COR, Lincoln, Nebraska, USA) with an automatic $\mathrm{CO}_{2}$ injector and an artificial blue and red light source. The microclimatic conditions in the chamber for sample measurements were maintained constant over the measurements: 1,200 $\mu \mathrm{mol} \mathrm{m} \mathrm{m}^{-2} \mathrm{~s}^{-1} \mathrm{PAR}$ (photosynthetic active radiation); $\mathrm{RH}$ (relative humidity) $53 \pm 7 \%$; $400 \mathrm{ppm} \mathrm{CO}_{2}$ and a leaf temperature of approximately $29.5 \pm 2.8^{\circ} \mathrm{C}$. The measurements started at approximately 10 a.m. and were performed with fully developed and healthy leaves from the middle third of the plants. Because of the indented shape of $A$. annua leaves and the need to estimate leaf area during the gas-exchange measurements, the leaves were photographed, and the area (only the area enclosed in the IRGA chamber) was calculated with the help of the area calculation tool of the open-source software GIMP (the GNU Image Manipulation Program).

\section{Phytochemical evaluation}

On March 20, 2010, when over $50 \%$ of plants started flowering, harvesting was performed. The plants were cut at the soil surface and dried in a convection oven at $\pm 35^{\circ} \mathrm{C}$ until constant weight was reached. After drying, the leaves were removed from the stalks for phytochemical analysis.

The assessed phytochemical traits were: the essential oil yield (EOY, $L$ ha $^{-1}$ ), the artemisinin content (ART, \%), the dihydro-deoxyarteannuin B content (DIH, \%), and the deoxyartemisinin content (DEO, \%).

Essential oil extraction was performed at the UTFPR Laboratory of Biochemistry and Plant Physiology. First, $150 \mathrm{~g}$ of dry leaves from each individual of $A$. annua $\mathrm{B}$ and $\mathrm{C}$ populations were transferred to a 2-L flask containing $1.5 \mathrm{~L}$ of distilled water which was coupled to a Clevenger system for the hydrodistillation process, which lasted $1.5 \mathrm{~h}$ after the beginning of condensation. After its volume was measured, the extracted oil was hermetically stored in amber glass bottles at $4^{\circ} \mathrm{C}$. The oil content was transformed into $\mathrm{L} \mathrm{ha}^{-1}$.

Analysis of artemisinin and its analogs was performed in the Phytochemistry Division of the Multidisciplinary Center for Chemical, Biological and Agricultural Research of the State University of Campinas [Centro Pluridisciplinar de Pesquisas Químicas, Biológicas e Agrícolas da Universidade Estadual de Campinas - CPQBA/ UNICAMP]. The extracts were obtained from 0.250 $\mathrm{g}$ of dried and ground leaves extracted with $5 \mathrm{~mL}$ of dichloromethane for $2 \mathrm{~min}$ in an Ultra Turrax (Quimis, Model Q-252, São Paulo, Brazil), followed by 2 x $5 \mathrm{~mL}$ of methanol for $3 \mathrm{~min}$ at $6000 \mathrm{rpm}$ at room temperature. The extract was vacuum filtered in a fritted funnel with filter paper and evaporated until dry in a rotary evaporator (Büchi, Model R2, Flawil, Switzerland).

During the extract purification, Florisil ${ }^{\circledR}$ cartridges (Strata-8B So13-hCh, Phenomenex, California, USA) were supplemented with an additional 5 g Florisi $^{\circledR}$ FX 0284-1 (60-100 mesh), and after being connected to the vacuum extraction system (Manifold, J.T. Baker, New Jersey, USA), these cartridges were conditioned with $10 \mathrm{~mL}$ hexane. Subsequently, the extract dissolved in $2 \mathrm{~mL}$ hexane was introduced into the system and eluted with $3 \mathrm{~mL}$ hexane and $60 \mathrm{~mL}$ dichloromethane, after which the fractions were separately collected. The dichloromethane fraction was evaporated until dry under vacuum in a rotary evaporator and resuspended in a 5-mL volumetric flask with highpressure liquid chromatography (HPLC) grade methanol. The samples were filtered and analyzed in triplicate by high-pressure liquid chromatograph coupled to a refractive index detector (HPLC/RI). A Waters liquid chromatograph (Massachusetts, USA), a Waters 515 pump and a Rheodyne injector valve with a $20-\mu \mathrm{L}$ sample loop were used. The system was coupled to a Waters $2414 \mathrm{RI}$ detector with the internal temperature detector set at $35^{\circ} \mathrm{C}$. The chromatographic data were analyzed by using Empower Pro Build 1154 software (Waters). A cyano stationary phase column (Luna CN $5 \mu \mathrm{m} 250$ x 4.6 $\mathrm{mm}$ ) (Phenomenex, California, USA), mobile phase $\mathrm{H}_{2} \mathrm{O}$ :methanol $(60: 40 \mathrm{v} / \mathrm{v})$, isocratic mode and a 1.0 $\mathrm{mL} / \mathrm{min}$ flow rate were used.

\section{Data analysis}

The existing relationship among the studied traits was estimated with a Pearson's correlation 
coefficient, and the significance level of correlations was established with t-test by using Genes statistical software (Cruz, 2001).

\section{RESULTS AND DISCUSSION}

Considering the agronomic, physiological and phytochemical traits for $2 / 39 \times 5 \times 3 \mathrm{M}$ variety (Table 1), significant positive correlations were observed between plant height $(\mathrm{Ht})$ and canopy height $(\mathrm{Hc})$; between the diameter of the canopy's lower section (DI) and the diameter of the canopy's middle section (Dm), the canopy volume (Vc) and the essential oil yield (EOY); among the diameter of the canopy's middle section (Dm) and the canopy volume (Vc) and the essential oil yield (EOY); among the canopy volume $(\mathrm{Vc})$ and the number of branches (NB) and the essential oil yield (EOY); among the $\mathrm{CO}_{2}$ assimilation rate $\left(P_{\mathrm{N}}\right)$ and the stomatal conductance $\left(g_{\mathrm{s}}\right)$ and the transpiration rate $(E)$; and between the stomatal conductance $\left(g_{\mathrm{s}}\right)$ and the transpiration rate $(E)$.

According to Favarin et al. (2002), the canopy volume $(\mathrm{Vc})$ shows a positive association with the leaf area index (LAI) in coffee plants, which have a conic shape similar to that of $A$. annua. The LAl is one of the most important biophysical parameters of the canopy because the LAl characterizes the plants' architecture and is related to the plant biomass (Linhares et al., 2000). However, it is assumed that the trait Vc can be used to estimate the biomass per plant in $A$. annua and, in the present study, the trait $\mathrm{Vc}$ showed a significant positive correlation with EOY $\left(r=0.94^{* *}\right)$ (Table 1), which indicates that the higher the canopy volume (biomass), the higher the essential oil yield. The positive correlation between biomass production and essential oil has been reported by several authors (Marchese \& Figueira, 2005; Marchese et al., 2005; Nalepa \& Carvalho, 2007; Mattana et al., 2010).

The significant positive correlation found between NB and $V c\left(r=0.72^{*}\right)$ indicates that the number of branches is effective in selecting plants with a higher canopy volume, which can also indicate gains in the production of essential oil, given that these two traits are highly correlated, as previously discussed.

Regarding the significant positive

Table 1. Phenotypic correlation coefficients among agronomic ${ }^{(1)}$, physiological(2) and phytochemical(3) traits evaluated for Artemisia annua L. 2/39x5x3M variety, Pato Branco, Paraná (PR), Brazil, 2010.

\begin{tabular}{|c|c|c|c|c|c|c|c|c|c|c|c|c|c|c|c|c|}
\hline Traits & $\mathrm{Ht}$ & $\mathrm{Hi}$ & $\mathrm{Hc}$ & DI & $\mathrm{Dm}$ & Du & Vc & Ds & NB & LA & $P_{\mathrm{N}}$ & $g_{\mathrm{s}}$ & $C_{i}$ & $E$ & WUE EOY & ART DIH \\
\hline \multicolumn{17}{|l|}{$\mathrm{Hi}$} \\
\hline \multicolumn{17}{|l|}{0.07} \\
\hline $\mathrm{Hc}$ & $1.00^{* *}$ & 0.03 & & & & & & & & & & & & & & \\
\hline $\mathrm{DI}$ & -0.17 & -0.41 & -0.15 & & & & & & & & & & & & & \\
\hline $\mathrm{Dm}$ & 0.21 & -0.27 & 0.22 & $0.82^{*}$ & & & & & & & & & & & & \\
\hline Du & 0.30 & -0.29 & 0.32 & 0.43 & 0.15 & & & & & & & & & & & \\
\hline Vc & 0.31 & -0.38 & 0.32 & $0.88^{* *}$ & $0.90^{* *}$ & 0.53 & & & & & & & & & & \\
\hline Ds & -0.46 & 0.10 & -0.46 & -0.21 & -0.45 & -0.24 & -0.47 & & & & & & & & & \\
\hline NB & 0.16 & -0.12 & 0.16 & 0.62 & 0.54 & 0.58 & $0.72^{*}$ & $-0.73^{*}$ & & & & & & & & \\
\hline LA & 0.50 & 0.30 & 0.49 & 0.05 & 0.39 & -0.15 & 0.25 & -0.40 & 0.01 & & & & & & & \\
\hline$P_{\mathrm{N}}$ & -0.67 & -0.32 & -0.66 & -0.02 & -0.30 & -0.32 & -0.33 & 0.13 & -0.15 & -0.18 & & & & & & \\
\hline$g_{\mathrm{s}}$ & $-0,41$ & -0.40 & -0.39 & 0.05 & -0.21 & 0.00 & -0.09 & -0.25 & 0.32 & -0.37 & $0.80^{*}$ & & & & & \\
\hline $\mathrm{C}_{\mathrm{i}}$ & 0.19 & 0.06 & 0.18 & -0.07 & -0.17 & 0.48 & 0.09 & -0.54 & 0.69 & -0.37 & -0.11 & 0.46 & & & & \\
\hline$E$ & -0.42 & -0.40 & -0.41 & -0.02 & -0.28 & -0.05 & -0.17 & -0.16 & 0.21 & -0.38 & $0.84^{* *}$ & $0.99^{* *}$ & 0.40 & & & \\
\hline WUE & -0.15 & -0.04 & -0.15 & 0.14 & 0.25 & -0.41 & -0.01 & 0.48 & -0.62 & 0.37 & -0.04 & -0.58 & $-0.98^{* *}$ & -0.54 & & \\
\hline EOY & 0.36 & -0.25 & 0.37 & $0.81^{*}$ & $0.91^{* *}$ & 0.46 & $0.94^{* *}$ & -0.56 & 0.64 & 0.48 & -0.38 & -0.25 & -0.04 & -0.34 & 0.14 & \\
\hline ART & -0.42 & -0.26 & -0.41 & -0.53 & -0.59 & -0.41 & $-0.72^{*}$ & 0.43 & $-0.72^{*}$ & -0.40 & 0.39 & 0.11 & -0.30 & 0.18 & $0.28-0.65$ & \\
\hline $\mathrm{DIH}$ & 0.49 & -0.43 & 0.51 & 0.01 & 0.31 & 0.09 & 0.22 & -0.36 & -0.14 & 0.43 & -0.28 & -0.36 & -0.30 & -0.37 & $0.38 \quad 0.42$ & 0.25 \\
\hline DEO & $-0.82^{*}$ & -0.01 & $-0.83^{*}$ & -0.18 & -0.41 & -0.39 & -0.51 & 0.29 & -0.14 & $-0.71^{*}$ & 0.51 & 0.47 & 0.16 & 0.48 & $-0.17-0.59$ & $0.57-0.46$ \\
\hline
\end{tabular}

(1) $\mathrm{Ht}$ : plant height; Hi: height of insertion of the first pair of plagiotropic branches; Hc: canopy height; DI: diameter of the canopy's lower section; Dm: diameter of the canopy's middle section; Du: diameter of the canopy's upper section; Ds: stem diameter; NB: number of branches; $V c$ : canopy volume; (2)LA: leaf area; $P_{\mathrm{N}}$ rate of $\mathrm{CO}_{2}$ assimilation; $g_{\mathrm{s}:}$ stomatal conductance; $\mathrm{C}_{\mathrm{i} \text { : }}$ intracellular concentration of $\mathrm{CO}_{2}$, $E$ : transpiration rate; WUE: water use efficiency; ${ }^{(3)}$ EOY: essential oil yield; ART: artemisinin content; DIH: dihydro-deoxyarteannuin B content; DEO: deoxyartemisinin content. ${ }^{* *}$ Significant at $1 \%$; ${ }^{*}$ significant at $5 \%$, according to a t-test. 
correlations found between the physiological traits $P_{\mathrm{N}}$ and $g_{\mathrm{s}}\left(r=0.80^{*}\right), P_{\mathrm{N}}$ and $E\left(r=0.84^{* *}\right)$ and $g_{\mathrm{s}}$ and $E\left(r=0.99^{* *}\right)$, it is evident that higher stomatal conductance corresponds to higher $\mathrm{CO}_{2}$ assimilation and transpiration rates, which was expected.

The negative correlations between some traits imply that an increase in one variable leads to a decrease in the other variable (Carvalho et al., 2004). The trait Vc exhibited a significant negative correlation with ART $\left(r=-0.72^{*}\right)$, which suggested that the higher the canopy volume, the lower the artemisinin production. Similar results were found by Magalhães et al. (2006), who showed that the biomass was negatively correlated $(r=-0.99)$ with the artemisinin content, which suggested that plants with a lower biomass have a higher artemisinin content. Additionally, Vaz et al. (2006) found a negative correlation between biomass production and artemisinin levels. These results agree with those of Marchese and Figueira (2005) and Marchese et al. (2010), who report that plants that prioritize the primary metabolism (e.g., biomass production) do so at the expense of secondary metabolism (e.g., artemisinin level). In contrast, Shukla et al. (1992) found a positive correlation $(r=0.67)$ between artemisinin yield and leaf production (biomass).

A significant negative correlation between NB and ART $\left(r=-0.72^{*}\right)$ was observed, which indicated that the larger the number of branches, the lower the artemisinin levels. This result is justified by the lack of artemisinin in the branches in addition to the presence of fatty compounds that hinder the extraction of this substance (Foglio, 1996; Magalhães et al., 1997; Rodrigues et al., 2006).

In addition, as shown in Table 1 , a negative correlation was observed between the phytochemical traits EOY and ART $(r=-0.65)$. Although not significant, this negative correlation indicates a tendency whereby the higher the essential oil yield, the lower the artemisinin levels. Similar results were presented by Wallart et al. (1999) in a study of tetraploid $A$. annua plants. These authors found that the levels of sesquiterpenes (artemisinin) increased, while those of monoterpenes (essential oil) decreased, which indicates an inverse reciprocal correlation between these two traits.

For 2/39x1V variety (Table 2), a significant positive correlation was observed among $\mathrm{Ht}$ and

TABLE 2. Phenotypic correlation coefficients among agronomic ${ }^{(1)}$, physiological(2) and phytochemical(3) traits evaluated for Artemisia annua L. 2/39x1V variety, Pato Branco, Paraná (PR), Brazil, 2010.

\begin{tabular}{|c|c|c|c|c|c|c|c|c|c|c|c|c|c|c|c|c|}
\hline Traits & $\mathrm{Ht}$ & $\mathrm{Hi}$ & $\mathrm{Hc}$ & DI & $\mathrm{Dm}$ & $\mathrm{Du}$ & Vc & Ds & NB & LA & $P_{\mathrm{N}}$ & $g_{\mathrm{s}}$ & $C_{i}$ & $E$ & WUE EOY & ART DIH \\
\hline $\mathrm{Hi}$ & 0.12 & & & & & & & & & & & & & & & \\
\hline $\mathrm{Hc}$ & $0.99^{* *}$ & 0.02 & & & & & & & & & & & & & & \\
\hline $\mathrm{DI}$ & $-0.76^{*}$ & 0.26 & $-0.79^{*}$ & & & & & & & & & & & & & \\
\hline $\mathrm{Dm}$ & -0.60 & -0.57 & -0.55 & 0.38 & & & & & & & & & & & & \\
\hline $\mathrm{Du}$ & $0.86^{\star *}$ & 0.33 & $0.83^{*}$ & -0.52 & -0.44 & & & & & & & & & & & \\
\hline Vc & -0.35 & 0.43 & -0.40 & $0.87^{* *}$ & 0.12 & -0.14 & & & & & & & & & & \\
\hline Ds & 0.45 & $-0.76^{*}$ & 0.53 & -0.64 & 0.16 & 0.20 & -0.56 & & & & & & & & & \\
\hline NB & -0.53 & 0.37 & -0.57 & $0.88^{* *}$ & 0.18 & -0.42 & $0.90^{* *}$ & -0.66 & & & & & & & & \\
\hline LA & -0.36 & -0.13 & -0.35 & 0.34 & 0.48 & -0.19 & 0.20 & 0.20 & 0.07 & & & & & & & \\
\hline$P_{\mathrm{N}}$ & 0.29 & -0.05 & 0.29 & -0.41 & -0.30 & 0.04 & -0.39 & 0.50 & -0.42 & 0.46 & & & & & & \\
\hline$g_{s}$ & -0.03 & -0.44 & 0.02 & -0.17 & 0.15 & -0.23 & -0.27 & 0.64 & -0.29 & $0.72^{*}$ & $0.82^{*}$ & & & & & \\
\hline $\mathrm{C}_{\mathrm{i}}$ & -0.25 & $-0.82^{*}$ & -0.16 & -0.08 & 0.55 & -0.29 & -0.29 & 0.58 & -0.28 & 0.42 & 0.06 & 0.56 & & & & \\
\hline E & 0.11 & -0.41 & 0.16 & -0.38 & -0.06 & -0.15 & -0.46 & 0.62 & -0.41 & 0.48 & $0.79^{*}$ & $0.92^{* *}$ & 0.59 & & & \\
\hline WUE & 0.16 & 0.54 & 0.10 & 0.15 & -0.26 & 0.22 & 0.34 & -0.26 & 0.22 & -0.05 & 0.16 & -0.24 & $-0.82^{*}$ & -0.47 & & \\
\hline EOY & -0.38 & -0.02 & -0.38 & 0.63 & 0.30 & -0.11 & 0.61 & -0.24 & 0.47 & 0.36 & -0.43 & -0.01 & 0.45 & -0.04 & -0.46 & \\
\hline ART & 0.32 & 0.33 & 0.29 & -0.27 & -0.49 & 0.10 & -0.14 & -0.21 & 0.12 & -0.42 & 0.06 & -0.12 & -0.22 & 0.19 & $-0.26-0.15$ & \\
\hline $\mathrm{DIH}$ & 0.16 & -0.41 & 0.20 & -0.65 & -0.02 & -0.20 & $-0.78^{*}$ & 0.40 & -0.52 & -0.37 & 0.30 & 0.14 & 0.02 & 0.25 & $-0.05-0.83^{*}$ & ${ }^{*} 0.22$ \\
\hline DEO & 0.37 & 0.43 & 0.33 & -0.06 & -0.27 & 0.47 & 0.17 & -0.11 & 0.13 & 0.21 & 0.14 & 0.11 & -0.03 & 0.26 & $-0.23 \quad 0.34$ & $0.62-0.41$ \\
\hline
\end{tabular}

${ }^{(1)} \mathrm{Ht}$ : plant height; Hi: height of insertion of the first pair of plagiotropic branches; Hc: canopy height; DI: diameter of the canopy's lower section; Dm: diameter of the canopy's middle section; Du: diameter of the canopy's upper section; Ds: stem diameter; NB: number of branches; $V c$ : canopy volume; (2)LA: leaf area; $P_{\mathrm{N}}$ rate of $\mathrm{CO}_{2}$ assimilation; $g_{\mathrm{s}:}$ stomatal conductance; $\mathrm{C}_{\mathrm{i}}$ intracellular concentration of $\mathrm{CO}_{2}$, $E$ : transpiration rate; WUE: water use efficiency; (3) EOY: essential oil yield; ART: artemisinin content; DIH: dihydro-deoxyarteannuin B content; DEO: deoxyartemisinin content. **Significant at $1 \%$; ${ }^{*}$ significant at $5 \%$, according to a t-test. 
$\mathrm{Hc}$ and $\mathrm{Du}$; between $\mathrm{Hc}$ and $\mathrm{Du}$; among $\mathrm{DI}$ and $\mathrm{Vc}$ and NB; between $\mathrm{Vc}$ and NB; among $g_{\mathrm{s}}$ and LA and $P_{\mathrm{N}}$ and among $E$ and $P_{\mathrm{N}}$ and $g_{s^{*}}$. These results were similar to those observed for $2 / 39 \times 5 \times 3 \mathrm{M}$ variety (Table 1). Thus, several correlations were confirmed for the two varieties, given that (similarly to $2 / 39 \times 5 \times 3 \mathrm{M}$ variety) there was a significant positive correlation between NB and $\mathrm{Vc}\left(r=0.90^{*}\right)$ for $2 / 39 \times 1 \mathrm{~V}$, which suggests that the number of branches is effective in the selection of plants with a higher canopy volume. Another significant positive correlation between the two varieties was between the physiological traits $P_{\mathrm{N}}$ and $g_{\mathrm{s}}\left(r=0.82^{*}\right) ; P_{\mathrm{N}}$ and $E\left(r=0.79^{*}\right)$ and $g_{s}$ and $E\left(r=0,92^{* *}\right)$.

However, for $2 / 39 \times 1 \mathrm{~V}$ variety (Table 2 ), there was not a significant positive correlation between any phytochemical trait (EOY, ART, DEO and IHL) and the agronomic traits. Similar results were obtained by Jain et al. (1996), who concluded that the synthesis and the accumulation of artemisinin are independent from the effect of metric traits such as plant height, stem diameter and dry matter production. In contrast, Paul et al. (2010) observed a positive correlation of artemisinin content with plant height and branch intensity, and Liao et al. (2009) suggested that taller plants with thick stalks and a moderate number of branches should be selected for the generation of a new $A$. annua variety with a high artemisinin content and yield.

Under the conditions of the present study, the results suggest that if $A$. annua breeding seeks to obtain essential oil, plants with a larger canopy volume should be selected, which will lead to gains in the yield of this substance. However, if the main interest is the artemisinin levels, plants with a smaller canopy volume and a smaller number of branches should be selected, which will lead to higher artemisinin levels. However, in this case, the increase in the production of the active principle occurs at the expense of the primary metabolism, which decreases biomass production, and, as a result, the artemisinin yield per planted area will be smaller.

\section{CONCLUSIONS}

The selection of plants with a larger canopy volume for $2 / 39 \times 5 \times 3 \mathrm{M}$ variety would enable indirect selection for essential oil yield.

The trait canopy volume was not effective in the selection of plants with a higher essential oil yield for 2/39x1V variety.

For both varieties, if the goal of breeding is higher artemisinin levels, plants with a large canopy volume and a large number of branches should be avoided.

\section{ACKNOWLEDGEMENTS}

The first author is grateful to the Brazilian National Agency for the Support and Evaluation of Graduate Education [Coordenação de Aperfeiçoamento de Pessoal de Nível Superior CAPES] for a scholarship.

\section{REFERENCES}

ALMEIDA, R.D.; PELUZIO, J.M.; AFFERRI, F.S. Correlações fenotípicas, genotípicas e ambientais em soja cultivada sob condições várzea irrigada, sul do Tocantins [Phenotypic, genotypic and environmental correlations in soybeans grown under irrigated lowland conditions, southern Tocantins]. Biosciense Journal, v.26, p.95-99, 2010.

CARVALHO, F.I.F. de; LORENCETTI, C.; BENIN, G. Estimativas e implicações da correlação no melhoramento vegetal [Estimates and implications of correlation in plant breeding]. Pelotas: Ed. Universitária da UFPel, 2004. 142 p.

CHARLES, D.J.; SIMON, J.E. Germoplasm variation in artemisinin content of Artemisia annua using an alternative method of artemisinin analysis from crude plant extracts. Journal of Natural Products, v.53, p.157-160, 1990.

CRUZ, C.D. Programa Genes: Aplicativo computacional em genética e estatística [Genes Program: A computer application for genetics and statistics]. Viçosa: Editora UFV, 2001. 648p.

CRUZ, C.D., REGAZZI, A.J. Modelos biométricos aplicados ao melhoramento genetic [Biometric models applied to genetic improvement]. Viçosa: Editora UFV, 2001. 390 p.

EFFERTH, T. Willmar Schwabe Award 2006: Antiplasmodial and Antitumor Activity of Artemisinin - From Bench to Bedside. Planta Med., v.73, p.299-309, 2007.

FAVARIN, J.L.; DOURADO NETO, D.; GARCIA, A.G.; VILLA NOVA, N.A.; FAVARIN, M.G.G.V. Equações para a estimativa do índice de área foliar do cafeeiro [Equations to estimate the leaf area index of coffee plants]. Pesquisa Agropecuária Brasileira, v.37, p. 769-773, 2002. FERREIRA, J.F.S.; JANICK, J. Distribution of artemisinin in Artemisia annua. In: JANICK, J. (Ed.). Progress in new crops. Arlington: ASHS Press, 1996. p.579-584.

FERREIRA, J.F.S. Artemisia annua L.: The hope against malaria and cancer. Medicinal and aromatic plant: Production, business and applications. 2004. Available at: <http://www.ars.usda.gov/SP2UserFiles/person/34667/ Ferreira-ArtemisiavsMalariaandCancer.pdf $>$. Accessed on: Nov. 10, 2010.

FOGLIO, Mary Ann. Um estudo químico de Artemisia annua L. aclimatada no Brasil [A chemical study of Artemisia annua L. acclimatized in Brazil]. 1996. 185p. Dissertation (Ph.D.). Universidade Estadual de Campinas, Campinas. Available at: < http://biq.iqm.unicamp.br/ arquivos/teses/vtls000107936.pdf>. Accessed on: Aug. 26, 2010.

JAIN, D.C.; MATHUR, A.K.; GUPTA, M.M.; SINGH, A.K.; VERMA, R.K.; GUPTA, A.P.; KUMAR, S. Isolation of high artemisinin-yielding clones of Artemisia annua. Phytochemistry, v.43, p.993-1001, 1996.

Rev. Bras. PI. Med., Botucatu, v.15, n.1, p.135-141, 2013. 
KUMAR, Sushil et al. High yields of artemisinin by multiharvest of Artemisia annua crops. Industrial Crops and Products, v.19, p.77-90, 2004.

LIAO, K.; WU, W.; ZHENG, Y.; LI, K.; LIU, Z. Correlation analysis on main agronomic characters, yield per plant, artemisinin percentage contents and total artemisinin content per plant of Artemisia annua. Zhongguo Zhong Yao Za Zhi, v.34, p.2299-2304, 2009.

LINHARES, C.A.; PONZONI, F.J.; SHIMABUKURO, Y.E. Relação entre volume de madeira e índice de área foliar em um povoamento de Pinus spp.: estudo de caso [The relationship between wood volume and leaf area index in a stand of Pinus spp.: a case study]. Revista Árvore, v.24, p.47-54, 2000.

MAGALHÃES, P.M. de. Seleção, melhoramento e nutrição da Artemisia annua L., para cultivo em região intertropical [Selection, improvement and nutrition of Artemisia annua L. for cultivation in an intertropical region]. 1996. 132p. Dissertation (Ph.D.) - Universidade Estadual de Campinas, Campinas.

MAGALHÃES, P.M. de; DELABAYS N.; SARTORATTO A. New hybrid lines of the antimalarial species Artemisia annua L. guarantee its growth in Brazil. Ciência e Cultura, v.49, p.413-415, 1997.

MAGALHÃES, P.M. de; FIGUEIRA, G.M.; REHDER, V.L.G.; SARTORATTO, A.; VAZ, A.P.A. Agronomic and chemical evaluation of a hybrid of the antimalarial species Artemisia annua L. for São Paulo state regions. Revista Brasileira de Plantas Medicinais, v.8, p.199-200, 2006. MAGALHÃES, P.M. de; PEREIRA, B.; SARTORATTO, A.; OLIVEIRA J. de; DEBRUNNER, N. New hybrid lines of the antimalarial species Artemisia annua L. Acta Horticulturae, v.502, p.377-381, 1999.

MAGALHÃES, P.M. de; PEREIRA, B.; SARTORATTO, A. Yields of antimalarial Artemisia annua L. species. Acta Horticulturae, v.629, p.421-424, 2004.

MARCHESE, J.A. Caracterização do mecanismo fotossintético e aspectos relacionados à floração de Artemisia annua L. [Characterization of the photosynthetic mechanism and aspects related to the flowering of Artemisia annua L.]. 2006. 68p. Thesis (Ph.D.) - Universidade Estadual Paulista, Botucatu.

MARCHESE, J.A.; BROETTO, F.; MING, L.C.; DUCATTI, C.; RODELLA, R.A.; VENTRELLA, M.C.; GOMES, G.D.R.; FRANCESCHI, L. de. Carbon isotope composition and leaf anatomy as a tool to characterize the photosynthetic mechanism of Artemisia annua L. Brazilian Journal Plant of Physiology, v.17, p. 187-190, 2005.

MARCHESE, J.A.; FERREIRA, J.F.S.; REHDER, V.L.G.; RODRIGUES, O. Water deficit effect on the accumulation of biomass and artemisinin in annual wormwood (Artemisia annua L., Asteraceae). Brazilian Journal Plant of Physiology, v. 22, p.1-9, 2010.

MARCHESE, J.A.; FIGUEIRA, G.M. O uso de tecnologias pré e pós-colheita e boas práticas agrícolas na produção de plantas medicinais e aromáticas [The use of pre- and post-harvest technology and good agricultural practices in the production of medicinal and aromatic plants]. Revista Brasileira de Plantas Medicinais, v.7, p.86-96, 2005. MARCHESE, J.A.; REHDER, V.L.G. Influência da temperatura na produção de artemisinina em Artemisia annua $\mathrm{L}$. [The influence of temperature on the production of artemisinin in Artemisia annua L.]. Revista Brasileira de Plantas Medicinais, v.4, p.89-93, 2001.

MATTANA, R.S. et al. Shade level effects on yield and chemical composition of leaf essential oil of Pothomorphe umbellata (L.) Miquel. Scientia Agricola, v.67, n.4, p.414418. 2010.

NALEPA, T.; CARVALHO, R.I.N. de. Produção de biomassa e rendimento de óleo essencial em camomila cultivada com diferentes doses de cama-de-aviário [Biomass production and essential oil yield in chamomile grown under different doses of bed-of-aviary]. Scientia Agraria, v.8, p.161-167, 2007.

NUNES, G.H.S.; BARROS, A.K.A.; QUEIROZ, M.A.; SILVA, R.A.; LIMA, L.L. Correlações entre características de meloeiro [Correlations among melon traits]. Caatinga, v.21, p.107-112, 2008.

PAUL, S.; KHANUJA, S.P.; SHASANY A.K.; GUPTA, M.M.; DAROKAR, M.P.; SAIKIA, D.; GUPTA, A.K. Enhancement of artemisinin content through four cycles of recurrent selection with relation to heritability, correlation and molecular marker in Artemisia annua L. Planta Med., v.76, p.1468-1472, 2010.

RODRIGUES, R.A.F.; FOGLIO, M.A.; BOAVENTURA JÚNIOR, S.; SANTOS, A.S.; REHDER, V.L.G. Otimização do processo de extração e isolamento do antimalárico artemisinina a partir de Artemisia annua L. [Optimization of the process of extraction and isolation of the antimalarial artemisinin from Artemisia annua L.]. Quimica Nova, v.29, p. 368-372, 2006.

SHUKLA, A.; FAROOQI, A.H.A.; SHUKLA, Y.N.; SHARMA, S. Effect of triacontanol and chlormequat on growth, plant hormones and artemisinin yield in Artemisia annua L. Plunk Growth Regulation, v.11, p.165-171, 1992.

VAZ, A.P.A.; SCARANARI, C.; BATISTA, L.A.R.; FIGUEIRA, G.M.; SARTORATTO, A.; MAGALHÃES, P.M. de. Biomassa e composição química de genótipos melhorados de espécies medicinais cultivadas em quatro municípios paulistas [The biomass and chemical composition of improved genotypes of medicinal species grown in four municipalities in Sao Paulo]. Pesquisa Agropecuária Brasileira, v.41, p.869-872, 2006.

WALLART, T.E.; PRAS, N.; QUAX, W.J. Seasonal variations of artemisinin and its biosynthetic precursors in tetraploid Artemisia annua plants compared with the diploid wild-type. Planta Med., v.65, p. 723-728, 1999. ZHANG, Long; YE, He-Chun; LI, Guo-Feng; Effect of development stage on the artemisinin content and the sequence characterized amplified region (SCAR) marker of high-artemisinin yielding strains of Artemisia annua L. Journal of Integrative Plant Biology, v.48, p.1054"1062, 2006.

Rev. Bras. PI. Med., Botucatu, v.15, n.1, p.135-141, 2013. 